\title{
Students' Perceptions of their Rights in Portugal
}

\author{
FELICIANO H. VEIGA \\ Center for Research in Education of theF aculty of Sciences of \\ the University of Lisbon, Portugal *
}

\begin{abstract}
The present study analyses young Portuguese students' perceptions of their rights at school and at home. The sample consisted of 294 male and female students, in Year 7 to Year 9, from several regions in the country. The assessment instrument used was the 'Children's Rights Scale' (Hart, 1993; Hart et al., 1996) and results were related to a number of other questions regarding the following independent variables: (1) school variables (school year, school achievement, teacher's support, violence at school); (2) family variables (parental authority, family cohesion, parents' education); (3) personal variables (age, gender, professional interests). Significant relations were found between the students' perceptions of their rights and these independent variables. In general, Portuguese students declare that their rights exist and are very important. Students who have a greater degree of personal limitations, or who live in worse school or family contexts, are the ones who indicate less importance and perceive less existence of rights at school and at home. The study gives directions to efforts to strengthen projects for the promotion of students' rights by including training programs for teachers and parents, in a close net connection among school, family and significant social agents.
\end{abstract}

On December 10, 1948, the Universal Dedaration of Human Rights was approved and gave recognition to the nobility of all human beings, with 'no kind of distinction, namely of race, color, sex, language, religion, political opinion, national or social origin, health, birth or any other

Address correspondence to: Feliciano Veiga, Center for Research in Education, Faculty of Sciences, University of Lisbon, Portugal. Email: fveiga@fc.ul.pt

This study was financed by J NICT/FCT and by thePRAXIS XXI Program for the period from 1997 to 2002 and devel oped at the Center for Research in Education of the Faculty of Sciences of the University of Lisbon (CIEFCUL)R. Ernesto Vasconcelos, E dif. C1-2o, 1749-016 Lisbon, Portugal.

School Psychology International Copyright (c) 2001 SAGE Publications (London, Thousand Oaks, CA and New Delhi), Vol. 22(2): 174-189. [0143-0343 (200105) 22:2; 174-189; 017974] 


\section{Veiga: Students' Perceptions of their Rights in Portugal}

situation'. It was mainly after Adolph Hitler's horrifying acts that the world community awakened to the need for a general framework in defence of Human Rights. However, fifty years have now passed and there arestill many transgressions and neglect of human rights, usually in war situations, but also in the treatment of minorities.

In the field of scientificinvestigation, there is a lack of specific studies which enable us to understand what is going on among disfavoured groups and about the rights of adolescents. The study reported in this article must be seen as a part of our contribution to the International Cross-National Children's Rights Research Project of the International School Psychol ogy Association (directed and coordinated from the Office for the Study of the Psychological Rights of the Child, Indiana University-Purdue University, Indianapolis). It has as a general purpose the analysis of young Portuguese students' perceptions of their rights at school and at home.

\section{Subjects}

Schools were chosen by random sampling from various places in Portugal to cover a wide spectrum of school types: rural, small town, suburban and urban schools. The sample consisted of 294 students, 48.7 percent males, 51.3 percent females; 23.2 percent were 12 -year-old, 24.8 percent were 13-year-old, and 52 percent 14-year-old; 34.6 percent were Y ear 7, 25.8 percent were Year 8 and 39.6 percent Year 9 . The great majority declared themselves to be Catholic (85.9 percent); while a small group reported noreligious affiliation (11.8 percent) and an even smaller group indicated that they followed other religions (2.3 percent).

Instruments and variables

In order to evaluate the rights, the Children's Rights Scale (Hart, 1993; Hart et al., 1996) was used. It is a questionnaire about the perceptions of the rights, with four response sets: existence at home; importance at home; existence at school; importance at school. The answers to the questionnaireweregiven by applying thefollowing Likert 5-point scales:

IMPORTANCE (for persons my age, the right should be given the following level of importance)

(1) Of no importance

(2) Of some importance

(3) Important

(4) Very important

(5) Of greatest importance

(?) Does not apply/don't know

EXISTENCE (For persons my age, theright existstothefollowing degree)

(1) Not at all 
School Psychology International (2001), Vol. 22(2)

(2) To a small degree

(3) To a medium degree

(4) To a large degree

(5) Fully supported

(?) Does not apply/don't know

For this exploratory stage of the study, items were organized within specific dimensions to facilitate the interpretation of the results. The rights expressed in each one of the items were considered to fall in the following dimensions or semantic units:

- self-determination (SD): 8, 10, 23, 24, 27, 28, 29 and 37;

- educational instruction (EI): 16, 17, 19, 26, 33, 35, 36 and 39;

- recognition-esteem (RE): 12, 20 and 31;

- social-emotional relationship (SE): 5, 13, 14, 15, 25 and 38;

- protection-security (PS): 1, 2, 3, 4, 11, 22, 30, 32, 34 and 40;

- basic provision (BP): 6, 7, 9, 18 and 21.

These semantic units relate directly to the model of human needs proposed by Maslow (1970), as well as to studies on the need of selffulfilment (Deci and Ryan, 1985). There is a parallelism between the sequence of psycho-social rights (basic provision, protection-security, social-emotional relationship, recognition-esteem, educational basis and self-fulfilment) and the disposition of the needs according to the well-known Maslow pyramid (physiological needs, need of security, bel onging, self-esteem, knowledge and self-fulfilment).

Table 1 presents the Cronbach-Alpha for dimensions, or semantic units, of the Children's Rights Scale (CRS), for the several groups. The al pha values exceed generally acceptable levels for this type of instruments (0.75). The greater coefficients appear in the whole sum of the scale (CRS-TOTAL), with al pha values superior to 0.90 , and the lessor coefficients appear in the dimension recognition-esteem, with values between 0.60 and 0.67 . This may have to do with a greater heterogeneity of the items in the relational dimension, or reflect some specificity presented by this dimension.

Thepossibilities of relationships between the psycho-social rights and other variables (considered as independent ones), led the authors to apply three additional instruments in the Portuguese project. Each required answers to be sel ected from a 6-point agreement scale- from 1 (totally disagree) to 6 (totally agree).

(a) The Confidence in one's Capacities Scale (Veiga, 1996), with the foll owing items taken out from theSCALE $(38,39,36,37,16,28,31$, $46,49)$. The al pha value was 0.75 .

(b) The Violence of Youths at Schools Scale (Veiga, 1995), which was built with the following items, taken from theEDEP: 1. I destroy or 
Veiga: Students' Perceptions of their Rights in Portugal

Table 1 Cronbach-Alpha for dimensions of the CRS, for the several groups

\begin{tabular}{|c|c|c|c|c|c|c|c|c|}
\hline \multirow[t]{2}{*}{ Groups } & \multicolumn{8}{|c|}{ Alpha values } \\
\hline & & SD & $\mathrm{EI}$ & RE & SE & PS & BP & CRS-TOTAL \\
\hline \multicolumn{9}{|c|}{ School - Existence } \\
\hline $\begin{array}{l}\text { Year } 7 \\
\text { Year } 8 \\
\text { Year } 9 \\
\text { Male } \\
\text { Female } \\
\text { Total }\end{array}$ & $\begin{array}{l}(N=103) \\
(N=077) \\
(N=117) \\
(N=145) \\
(N=152) \\
(N=294)\end{array}$ & $\begin{array}{l}0.81 \\
0.80 \\
0.82 \\
0.80 \\
0.81 \\
0.82\end{array}$ & $\begin{array}{l}0.85 \\
0.83 \\
0.84 \\
0.85 \\
0.84 \\
0.84\end{array}$ & $\begin{array}{l}0.61 \\
0.60 \\
0.62 \\
0.60 \\
0.61 \\
0.60\end{array}$ & $\begin{array}{l}0.76 \\
0.75 \\
0.75 \\
0.76 \\
0.75 \\
0.76\end{array}$ & $\begin{array}{l}0.83 \\
0.82 \\
0.83 \\
0.83 \\
0.82 \\
0.83\end{array}$ & $\begin{array}{l}0.76 \\
0.75 \\
0.75 \\
0.76 \\
0.75 \\
0.76\end{array}$ & $\begin{array}{l}0.97 \\
0.93 \\
0.94 \\
0.95 \\
0.95 \\
0.94\end{array}$ \\
\hline \multicolumn{9}{|c|}{ School - Importance } \\
\hline $\begin{array}{l}\text { Year } 7 \\
\text { Year } 8 \\
\text { Year } 9 \\
\text { Male } \\
\text { Female } \\
\text { Total }\end{array}$ & $\begin{array}{l}(\mathrm{N}=103) \\
(\mathrm{N}=077) \\
(\mathrm{N}=117) \\
(\mathrm{N}=145) \\
(\mathrm{N}=152) \\
(\mathrm{N}=294)\end{array}$ & $\begin{array}{l}0.75 \\
0.76 \\
0.75 \\
0.77 \\
0.75 \\
0.76\end{array}$ & $\begin{array}{l}0.84 \\
0.82 \\
0.83 \\
0.82 \\
0.83 \\
0.82\end{array}$ & $\begin{array}{l}0.63 \\
0.65 \\
0.65 \\
0.63 \\
0.61 \\
0.65\end{array}$ & $\begin{array}{l}0.76 \\
0.75 \\
0.75 \\
0.75 \\
0.76 \\
0.76\end{array}$ & $\begin{array}{l}0.81 \\
0.80 \\
0.80 \\
0.81 \\
0.80 \\
0.81\end{array}$ & $\begin{array}{l}0.71 \\
0.75 \\
0.75 \\
0.70 \\
0.70 \\
0.75\end{array}$ & $\begin{array}{l}0.96 \\
0.94 \\
0.95 \\
0.95 \\
0.92 \\
0.95\end{array}$ \\
\hline \multicolumn{9}{|c|}{ Home - Existence } \\
\hline $\begin{array}{l}\text { Year } 7 \\
\text { Year } 8 \\
\text { Year } 9 \\
\text { Male } \\
\text { Female } \\
\text { Total }\end{array}$ & $\begin{array}{l}(\mathrm{N}=103) \\
(\mathrm{N}=077) \\
(\mathrm{N}=117) \\
(\mathrm{N}=145) \\
(\mathrm{N}=152) \\
(\mathrm{N}=294)\end{array}$ & $\begin{array}{l}0.83 \\
0.80 \\
0.82 \\
0.82 \\
0.83 \\
0.82\end{array}$ & $\begin{array}{l}0.89 \\
0.88 \\
0.89 \\
0.89 \\
0.88 \\
0.88\end{array}$ & $\begin{array}{l}0.66 \\
0.65 \\
0.66 \\
0.65 \\
0.66 \\
0.67\end{array}$ & $\begin{array}{l}0.81 \\
0.80 \\
0.80 \\
0.81 \\
0.80 \\
0.81\end{array}$ & $\begin{array}{l}0.86 \\
0.80 \\
0.82 \\
0.83 \\
0.84 \\
0.86\end{array}$ & $\begin{array}{l}0.82 \\
0.81 \\
0.83 \\
0.81 \\
0.84 \\
0.86\end{array}$ & $\begin{array}{l}0.96 \\
0.91 \\
0.96 \\
0.96 \\
0.95 \\
0.96\end{array}$ \\
\hline \multicolumn{9}{|c|}{ Home - Importance } \\
\hline $\begin{array}{l}\text { Year } 7 \\
\text { Year } 8 \\
\text { Year } 9 \\
\text { Male } \\
\text { Female } \\
\text { Total }\end{array}$ & $\begin{array}{l}(\mathrm{N}=103) \\
(\mathrm{N}=077) \\
(\mathrm{N}=117) \\
(\mathrm{N}=145) \\
(\mathrm{N}=152) \\
(\mathrm{N}=294)\end{array}$ & $\begin{array}{l}0.76 \\
0.75 \\
0.79 \\
0.75 \\
0.77 \\
0.75\end{array}$ & $\begin{array}{l}0.83 \\
0.82 \\
0.84 \\
0.82 \\
0.84 \\
0.82\end{array}$ & $\begin{array}{l}0.60 \\
0.62 \\
0.61 \\
0.62 \\
0.60 \\
0.61\end{array}$ & $\begin{array}{l}0.76 \\
0.76 \\
0.77 \\
0.75 \\
0.76 \\
0.75\end{array}$ & $\begin{array}{l}0.81 \\
0.80 \\
0.82 \\
0.81 \\
0.80 \\
0.81\end{array}$ & $\begin{array}{l}0.71 \\
0.70 \\
0.71 \\
0.70 \\
0.74 \\
0.80\end{array}$ & $\begin{array}{l}0.95 \\
0.93 \\
0.95 \\
0.95 \\
0.93 \\
0.95\end{array}$ \\
\hline
\end{tabular}

Note: BP, basic provision; PS, protection-security; SE, social-emotional relationship; RE, recognition-esteem; EI, educational instruction; SD, self-determination.

intentionally damage school property; 2 . I hit my colleagues physically; 3. I hit my teachers physically; 4 . I swear in class; 5 . I hit my teachers verbally; 6. I hit my colleagues verbally; 7. I threaten people at school. The al pha value was 0.83 .

(c) The Perception of Parental Support Scale (Veiga, 1997; 1999), which includes five items: 1 . My father cares about my studies; 2. My mother cares about my studies; 3. My parents think I am an 
School Psychol ogy I nternational (2001), Vol. 22(2)

intelligent student; 4. My father likes my friends; 5. My mother likes my friends. The al pha value was 0.80 .

The enquiry also included specific questions designed to evaluate the independent variables: perception of teacher's support; brotherhood; parental authority; parents' education; family cohesion; aimed profession; and exposure to aggressive TV programs; school achievement; number of school failures.

The variable perception of teachers' support was evaluated by means of the item I can feel the support of teachers in school. The same procedure was followed to evaluate the item brotherhood; and the item exposure to aggressi ve TV programs. The available answers were yes or no. Parental authority was evaluated by means of the item my parents deal with me in an authoritarian, understanding or indifferent manner. The available choices are only understanding versus authoritarian. Parents' education means the average of father's and mother's years of education. Two groups were defined: low level (the average of both parents' education rates less than Year 9) and average/high level (the average rates equal to or greater than Y ear 9). The variable family cohesion was divided into two categories: students with separated/divorced parents versus married parents. The aimed profession was evaluated by means of the item Which profession would you like to have?'. The profession was considered high if it implied having a university course, and low if it did not. The variables of school achievement were: Natural Sciences (NC), Mathematics (MAT), History (HIST) and M other L anguage (ML). In each subject achievement was to be classified from 1 (lowest achievement) to 5 (highest achievement).

Questions of study

A first objective of the survey was to determine the relative position of each one of therights. M orespecifically, thefollowing questions of study were stated:

1. What is the degree of existenceand the degree of importance given to each one of the rights at school and at home?

2. Aretherestatistically significant differences between themean scale values on the Children's Rights Scale (CRS) for groups of distinctive students, according to each one of the following independent variables: school year (Year 9 versus Years 7/8), number of school failures (with failures versus no failures), parents' education (low versus average/high level), family cohesion (separation/divorce versus marriage), parental authority (authoritarian versus understanding), age (12- to13-years-old versus 14-years-old), gender, aimed profession 
Veiga: Students' Perceptions of their Rights in Portugal

(low versus high), and exposure to aggressive TV programs (yes versus no)?

3. How do the results between each one of the Children's Rights Scale (CRS) dimensions and each one of the following independent variables correlate: school achievement, teachers' support, violence at school, parental support, brotherhood and trust in each ones' capacities?

It must be stressed that, due to a great lack of previous studies, the results which arepresented can only beseen as bel onging totheexploratory type.

\section{Procedure}

The data were collected during 1995, following project guidelines. The students of the classes included in the study filled in the questionnaires, supervised by their teachers. They performed this task during regular class time and were given as much time as they needed. The students participated in the research on a volunteer basis.

\section{Results}

Highest and lowest scaled items

The top and bottom five items, according to mean scale values, for existenceand importanceat school and at homearepresented in Table 2. For school-existence, the rights judged of lower existence appear in the dimensions of protection-security (items 1, 3, 4), basic provision (item 21), and in self-determination (item 23). For these items, the average scalevalueis between thetoa medium degreeand toa largedegreel evels. The rights at the top, of greater existence, appear in the dimensions of social-emotional relationship (items 5, 13 and 15), educational instruction (item 19), and recognition-esteem (item 20). For these items, the average scale value is between the to a large degreeand fully supported levels.

For school-importance, the rights judged of lesser importance are in thedimensions of self-determination (23,8 and 28), basic provision (item 21 ), and protection-security (item 3). The ones seen as being of greater importance are in the dimensions of protection-security (item 11), basic provision (items 18 and 6), social-emotional relationship (13) and educational instruction (item 26). I tem 23 is the only one which appears between the parameters important and very important. The other items are situated between the parameters very important and of greatest importance.

For home-existence, the items judged as existing at lower levels are 
Table 2 Top five and bottom five items, for the existence and importance of rights at school and at home (the dimensions are in parenthesis)

\begin{tabular}{|c|c|c|c|c|c|}
\hline Items & $\begin{array}{c}\text { School } \\
\text { Top } 5 \text { Existence I tems }\end{array}$ & Mean & Items & $\begin{array}{c}\text { Home } \\
\text { Top } 5 \text { Existencel tems }\end{array}$ & Mean \\
\hline $\begin{array}{l}\text { (SE) } 05 \\
\text { (SE) } 13 \\
\text { (RE) } 20 \\
\text { (SE) } 15 \\
\text { (EI) } 19 \\
\text { Items } \\
\text { (SD) } 23 \\
\text { (BP) } 21 \\
\text { (PS) } 04 \\
\text { (PS) } 03 \\
\text { (PS) } 01\end{array}$ & $\begin{array}{l}\text { To be a good friend to others } \\
\text { To have the opportunity to have good ... } \\
\text { To have your own special name... } \\
\text { To be able to be with friends you have... } \\
\text { To be able to go as far in school ... } \\
\text { Bottom } 5 \text { Existence I tems } \\
\text { To have money to spend as you ... } \\
\text { To have time and a place to be alone ... } \\
\text { To be treated fairly when people think ... } \\
\text { To have people look after you and ... } \\
\text { To be given help by experts when ... }\end{array}$ & $\begin{array}{c}4.22 \\
4.18 \\
4.17 \\
4.11 \\
4.03 \\
\text { Mean } \\
3.41 \\
3.39 \\
3.30 \\
3.26 \\
3.19\end{array}$ & $\begin{array}{l}\text { (RE) } 20 \\
\text { (BP) } 06 \\
\text { (BP) } 09 \\
\text { (EI) } 35 \\
\text { (EI) } 26 \\
\text { I tems } \\
\text { (SD) } 08 \\
\text { (PS) } 01 \\
\text { (PS) } 03 \\
\text { (PS) } 04 \\
\text { (SD) } 23\end{array}$ & $\begin{array}{l}\text { To have your own special name from .... } \\
\text { To be given medical help when you ... } \\
\text { To have food, clothing, and a place... } \\
\text { To have a place to study } \\
\text { To have a chance to learn what is ... } \\
\text { Bottom } 5 \text { Existence I tems } \\
\text { To influence decisions about what ... } \\
\text { To be given hel p by experts when ... } \\
\text { To have people look after you and... } \\
\text { To be treated fairly when people think .. } \\
\text { To have money to spend as you choose }\end{array}$ & $\begin{array}{c}4.61 \\
4.54 \\
4.50 \\
4.48 \\
4.45 \\
\text { Mean } \\
4.06 \\
3.99 \\
3.96 \\
3.78 \\
3.44\end{array}$ \\
\hline Items & $\begin{array}{c}\text { School } \\
\text { Top } 5 \text { I mportance I tems }\end{array}$ & Mean & Items & $\begin{array}{c}\text { Home } \\
\text { Top } 5 \text { I mportance I tems }\end{array}$ & Mean \\
\hline $\begin{array}{l}\text { (PS) } 11 \\
\text { (BP) } 18 \\
\text { (BP) } 06 \\
\text { (SE) } 13 \\
\text { (EI) } 26 \\
\text { I tems } \\
\text { (SD) } 28 \\
\text { (BP) } 21 \\
\text { (SD) } 08 \\
\text { (PS) } 03 \\
\text { (SD) } 23\end{array}$ & $\begin{array}{l}\text { To be respected for your religion ... } \\
\text { To be given help quickly when very ... } \\
\text { To be given medical help when you ... } \\
\text { To have the opportunity to have good ... } \\
\text { To have a chance to learn what is ... } \\
\text { Bottom } 5 \text { I mportancel tems } \\
\text { To be able to choose your own religion .... } \\
\text { To have time and a place to be alone... } \\
\text { To influence decisions about what will ... } \\
\text { To have people look after you and ... } \\
\text { To have money to spend as you choose }\end{array}$ & $\begin{array}{l}4.74 \\
4.74 \\
4.70 \\
4.63 \\
4.62 \\
\text { Mean } \\
4.36 \\
4.32 \\
4.31 \\
4.16 \\
3.58\end{array}$ & $\begin{array}{l}\text { (BP) } 06 \\
\text { (BP) } 09 \\
\text { (BP) } 07 \\
\text { (PS) } 11 \\
\text { (SE) } 25 \\
\text { I tems } \\
\text { (RE) } 12 \\
\text { (SE) } 15 \\
\text { (SD) } 08 \\
\text { (PS) } 03 \\
\text { (SD) } 23\end{array}$ & $\begin{array}{l}\text { To be given medical help when you ... } \\
\text { To have food, clothing, and a place to... } \\
\text { To grow up strong and healthy in mind . } \\
\text { To be respected for your religion ... } \\
\text { To be with people who love and care... } \\
\text { Bottom } 5 \text { I mportance I tems } \\
\text { To have your needs and wishes... } \\
\text { To be able to be with friends you have... } \\
\text { To influence decisions about what will .. } \\
\text { To have people look after you and ... } \\
\text { To have money to spend as you choose }\end{array}$ & $\begin{array}{r}4.85 \\
4.84 \\
4.81 \\
4.80 \\
4.80 \\
\text { Mean } \\
4.45 \\
4.43 \\
4.40 \\
4.38 \\
3.65\end{array}$ \\
\hline
\end{tabular}

Note: Dimensions of the items: BP, Basic Provision; PS, Protection-Security; SE, Social-Emotional Relationship; RE, Recognition-Esteem; EI, Educational Instruction; SD, Self-determination. 


\section{Veiga: Students' Perceptions of their Rights in Portugal}

related to the dimensions of self-determination (items 8,23 ) and protection-security (items $1,3,4)$. The average scale value for the last four items $(1,3,4,23)$ falls between exists to a medium degreand to a large degreelevels. For item 8 , the average scale value falls between exists to a large degree and fully supported levels. Among the items judged to be at greater existencelevels are some bel onging in the dimensions of basic provision (items 9, 6), educational instruction $(26,35)$ and recognitionesteem (item 20). For these items, the average scale value falls between exists to a large degree and fully supported levels.

For home-importance, theitems identifiedasless important arein the dimensions self-determination (items 23,8 ), protection-security (item $3)$, social-emotional relationship (item 15), and recognition-esteem (item 12). The ones seen as more important are in the dimensions basic provision (items $6,9,7$ ), protection-security (item 11) and socialemotional relationship (item 25). For home-importance, item 23 is the only one with an average scale value between important and very important levels; the average scale values for the other items fall between very important and the parameter of greatest importancelevels.

\section{General Findings}

Considering the average scale values of the 40 rights (items), the following can be observed: the importance of rights at school $(M=4.47)$ issignificantly greater than theexistence $(M=3.77)(t=7.71 ; p<0.001)$; the importance of rights at home $(M=4.58)$ is significantly greater than the existence $(M=4.23)(t=4.39 ; p<0.001)$; the existence of rights at home $(M=4.23)$ is significantly greater than at school $(M=3.77)(t=5.3$; $p<0.001)$; the importance of rights at home $(M=4.58)$ is significantly greater than at school $(4.47)(t=2.23 ; p<0.5)$.

Table 3 presents the number of subjects, means and standard deviations of the results in the Children's Rights Scale (CRS) dimensions, as well as the significance of thet values for the contrasts: school-existence versus school-importance, home-existence versus home-importance, school-existenceversus home-existence, and school-importanceversus home-importance.

The results for the Children's Rights Scale (CRS) dimensions also point out that: theimportance of rights at school aresignificantly greater than its existence, at school and at home, in all the dimensi ons of the CRS $(p<0.001)$; the importance of rights at home are significantly greater than its existence, in all the dimensions of the CRS $(p<0.001)$; the existence of rights at homeare significantly greater than at school, in all the dimensions of the CRS ( $p<0.001)$; the importance of rights at home aresignificantly greater than at school, in all thedimensions of theCRS, exception made to esteem and self-determination.

Table 4 presents the significance of the $t$ values obtained in the 
School Psychology International (2001), Vol. 22(2)

Table 3 Number of subjects, means and standard deviation of the results in the CRS dimensions, with t values and significance for various contrasts

\begin{tabular}{|c|c|c|c|c|c|c|c|c|}
\hline \multirow{2}{*}{$\begin{array}{l}\text { Contrast } \\
\text { Dimension }\end{array}$} & \multicolumn{3}{|c|}{ School - Existence } & \multicolumn{3}{|c|}{ School - Importance } & \multirow[b]{2}{*}{$\mathrm{t}$} & \multirow[b]{2}{*}{ Sig. } \\
\hline & Mean & Std & $\mathrm{N}$ & Mean & Std & & & \\
\hline Self-determination & 29.5 & 4.8 & 208 & 34.7 & 3.9 & 231 & -12.4 & $* * *$ \\
\hline Instruction & 31.6 & 5.2 & 234 & 36.6 & 3.7 & 255 & -12.2 & *** \\
\hline Esteem & 11.6 & 2.1 & 243 & 13.4 & 1.7 & 256 & -10.5 & $* * *$ \\
\hline Relation & 24.1 & 3.5 & 247 & 27.0 & 2.9 & 267 & -10.2 & $* * *$ \\
\hline Protection & 36.0 & 6.2 & 186 & 44.5 & 4.4 & 224 & -15.7 & *** \\
\hline Provision & 19.1 & 3.3 & 223 & 23.1 & 2.2 & 248 & -15.3 & *** \\
\hline Total & 154.4 & 21.2 & 132 & 181.3 & 15.8 & 169 & -12.2 & $* * *$ \\
\hline Contrast & \multicolumn{3}{|c|}{ Home- Existence } & \multicolumn{3}{|c|}{ Home-Importance } & & \\
\hline Dimension & Mean & Std & $N$ & Mean & Std & $\mathrm{N}$ & $\mathrm{t}$ & Sig. \\
\hline Self-determination & 32.6 & 4.8 & 247 & 35.3 & 3.6 & 262 & -7.2 & $* * *$ \\
\hline Instruction & 35.2 & 4.6 & 255 & 37.4 & 3.2 & 275 & -6.3 & $* * *$ \\
\hline Esteem & 13.1 & 1.8 & 277 & 13.6 & 1.6 & 284 & -3.5 & $* * *$ \\
\hline Relation & 25.5 & 3.6 & 266 & 27.6 & 2.5 & 281 & -7.9 & *** \\
\hline Protection & 42.0 & 5.8 & 242 & 45.9 & 3.9 & 264 & -8.8 & *** \\
\hline Provision & 21.9 & 3.0 & 259 & 23.8 & 1.5 & 278 & -9.2 & *** \\
\hline Total & 172.1 & 20.0 & 183 & 185.0 & 12.9 & 221 & -7.5 & $* * *$ \\
\hline Contrast & \multicolumn{3}{|c|}{ School - Existence } & \multicolumn{3}{|c|}{ Home-Existence } & & \\
\hline Dimension & Mean & Std & $\mathrm{N}$ & Mean & Std & $\mathrm{N}$ & $\mathrm{t}$ & Sig. \\
\hline Self-determination & 29.5 & 4.8 & 208 & 32.6 & 4.8 & 247 & -6.9 & $* * *$ \\
\hline Instruction & 31.6 & 5.2 & 234 & 35.2 & 4.6 & 255 & -8.1 & $* * *$ \\
\hline Esteem & 11.6 & 2.1 & 243 & 13.1 & 1.8 & 277 & -8.6 & $* * *$ \\
\hline Relation & 24.1 & 3.5 & 247 & 25.5 & 3.6 & 266 & -4.5 & *** \\
\hline Protection & 36.0 & 6.2 & 186 & 42.0 & 5.8 & 242 & -10.2 & *** \\
\hline Provision & 19.1 & 3.3 & 223 & 21.9 & 3.0 & 259 & -9.7 & *** \\
\hline Total & 154.4 & 21.2 & 132 & 172.1 & 20.0 & 183 & -7.5 & $* * *$ \\
\hline Contrast & \multicolumn{3}{|c|}{ School - I mportance } & \multicolumn{3}{|c|}{ Home-I mportance } & & \\
\hline Dimension & Mean & Std & $\mathrm{N}$ & Mean & Std & $\mathrm{N}$ & $\mathrm{t}$ & Sig. \\
\hline Self-determination & 34.7 & 3.9 & 231 & 35.3 & 3.6 & 262 & -1.8 & ns \\
\hline Instruction & 36.6 & 3.7 & 255 & 37.4 & 3.2 & 275 & -2.7 & $* *$ \\
\hline Esteem & 13.4 & 1.7 & 256 & 13.6 & 1.6 & 284 & -1.4 & ns \\
\hline Relation & 27.0 & 2.9 & 267 & 27.6 & 2.5 & 281 & -2.5 & $*$ \\
\hline Protection & 44.5 & 4.4 & 224 & 45.9 & 3.9 & 264 & -3.7 & $* * *$ \\
\hline Provision & 23.1 & 2.2 & 248 & 23.8 & 1.5 & 278 & -4.2 & *** \\
\hline Total & 181.3 & 15.8 & 169 & 185.0 & 12.9 & 221 & -2.5 & $*$ \\
\hline
\end{tabular}

$* \mathrm{p}<0.05 ; * * \mathrm{p}<0.01 ; * * * \mathrm{p}<0.001 ; \mathrm{ns}=$ not significant. 
Veiga: Students' Perceptions of their Rights in Portugal

Table 4 Significance of $t$ values obtained in the rights, according to the independent variables: school, home and personal

\begin{tabular}{|c|c|c|c|c|c|c|c|c|c|}
\hline \multirow[t]{2}{*}{ Rights } & \multicolumn{9}{|c|}{ Variables: school, home and personal } \\
\hline & SY & $\mathrm{SF}$ & PED & PA & $\mathrm{FC}$ & AGE & GEN & PRO & ATV \\
\hline \multicolumn{10}{|l|}{ School - Existence } \\
\hline Self-determination & & & & $* * *$ & $*$ & & & $*$ & \\
\hline Instruction & $* *$ & & $*$ & $* * *$ & & $*$ & & & \\
\hline Esteem & $*$ & $*$ & $*$ & $*$ & & & & & $*$ \\
\hline $\begin{array}{l}\text { Relation } \\
\text { Protection }\end{array}$ & & $*$ & $*$ & $\begin{array}{l}* \\
*\end{array}$ & $*$ & & & $*$ & $*$ \\
\hline \multicolumn{10}{|l|}{ School - Importance } \\
\hline $\begin{array}{l}\text { Self-determination } \\
\text { Instruction }\end{array}$ & $*$ & & $*$ & $* *$ & & $*$ & $* * *$ & $* *$ & \\
\hline $\begin{array}{l}\text { Esteem } \\
\text { Relation }\end{array}$ & $* * *$ & $\begin{array}{l}* \\
* *\end{array}$ & $*$ & $*$ & & & $\begin{array}{c}* \\
* * *\end{array}$ & $*$ & $*$ \\
\hline Protection & & & & & & & & & $* * *$ \\
\hline \multicolumn{10}{|l|}{ Home-Existence } \\
\hline Self-determination & & $*$ & $* * *$ & $* * *$ & $*$ & & & $* * *$ & \\
\hline Instruction & $*$ & $* *$ & $* * *$ & $* * *$ & & $*$ & & $*$ & \\
\hline Esteem & $* *$ & & $* * *$ & $* *$ & & $*$ & & $* * *$ & $*$ \\
\hline Relation & $*$ & & $* * *$ & $*$ & & $*$ & & $* * *$ & \\
\hline $\begin{array}{l}\text { Protection } \\
\text { Provision }\end{array}$ & $*$ & $* * *$ & $\begin{array}{l}* * * \\
* * *\end{array}$ & $*$ & $*$ & $*$ & & $*$ & $*$ \\
\hline \multicolumn{10}{|l|}{ Home- I mportance } \\
\hline Self-determination & & $* * *$ & $* *$ & $*$ & & *** & ** & $\begin{array}{l}* * \\
* * *\end{array}$ & \\
\hline Esteem & $* *$ & & & & & $* *$ & $*$ & $*$ & $*$ \\
\hline Relation & $*$ & & $*$ & $*$ & & $*$ & $*$ & $*$ & \\
\hline Protection & $* * *$ & $* * *$ & & & & $* *$ & & $*$ & $* * *$ \\
\hline
\end{tabular}

$* \mathrm{p}<0.05 ; * * \mathrm{p}<0.01 ; * * * \mathrm{p}<0.001$

SY, school year; SF, number of years of school failure; PED, parents' education; PA, parental authority; FC, family cohesion; AGE, student's age; GEN , student's gender; PRO, aimed profession; ATV, exposure to aggressive TV programs

dimensions of the rights, according to relationships with the independent variables: school year (Year 9 versus Years 7/8), number of school failures (failures versus no failures), parents' education (low versus average/high level), parental authority (authoritarian versus understanding), family cohesion (separation/divorce versus marriage), gender, age (12- to 13-year-old versus 14-year-old) aimed profession (low versus high), and exposure to aggressive TV programs (yes versus no).

It must benoted that for existence, as well as importance, the average scale values are higher for subjects of the following groups (when 
compared with the respective contrast groups): without school failure, with an average/high parents' education, with an appreciation of parental authority, with a married family (not separated/divorced), wishing to have a high professional level and dislike for aggressive television. The differences considering age, as well as school year, favour the younger students (12-to 13-year-old), together with students in school years $7 / 8$, for school existence. However, for theimportance of the rights, the older students, as well as the students in school year 9 are the ones who provide the higher scale value averages. For gender there are no statistically significant differences in the existence of the rights. However, girls provide higher average scale values for the importance given to some dimensions of the rights: relationship, esteem and instruction.

For school-existence, provision doesn't present any kind of differentiation. The larger differentiation appears for esteem, with five significant differences. The dimensions instruction and relation have four significant points of variation; self-determination and protection have only three. Self-determination is the dimension of rights with the most variation (9), followed by therelation and protection (with 7), instruction (5), esteem (4) and provision (3). The variable which appears to have a greater power of differentiation is parental authority; the variable presenting a minor power of differentiation is gender.

For school-importance novariation on the oscillation of the results for provision appears. The greater oscillation in the results did occur in relation. The variable family cohesion does not differentiateany dimension of the rights.

For home-existence, it can be observed that the dimension provision varies with the parents' education (PED)Higher values are positively related tosubjects whohavea medium/high parents' education $(p<0.001)$. Thedimensions protection, esteem and instruction vary with most of the independent variables. Although they appear in a minor quantity, the dimensions relation and self-determination do present statistically significant variations according to independent variables. Among these, the ones which revealed a greater power of differentiation were level of parents' education (PED) (always with $p<0.001$ ), parental authority (PA) and aimed profession (PRO); the one which appeared to have a minor power of differentiation was gender.

For home-importance, provision doesn't present any sort of oscillation for independent variables. Relation and instruction present the same quantity of differentiations (6); esteem and protection present five differentiations; self-determination only varied according to the family authority and aimed profession. The independent variables with a greater power of differentiation in the dimensions of the rights were aimed profession, school year and age; the one which revealed a minor power of differentiation was family cohesion. 


\section{Veiga: Students' Perceptions of their Rights in Portugal}

Table 5 Correlation coefficients between the dimensions of the rights and the variables: school, home and personal

\begin{tabular}{|c|c|c|c|c|c|c|c|c|c|}
\hline \multirow[t]{2}{*}{ Rights } & \multicolumn{9}{|c|}{ Variables: school, home and personal } \\
\hline & NC & MAT & HIS & ML & VIOL & PTS & PPS & $\mathrm{BR}$ & $\mathrm{TC}$ \\
\hline \multicolumn{10}{|l|}{ School - Existence } \\
\hline \multicolumn{10}{|l|}{ Self- } \\
\hline Instruction & & & & & $-0.18^{*}$ & $0.35^{* * *}$ & * $0.29 * *$ & $0.15^{*}$ & $0.22 * *$ \\
\hline Esteem & & & & & $-0.15^{*}$ & $0.44^{* * *}$ & *0.32** & & $0.19 *$ \\
\hline Relation & $0.15^{*}$ & & $0.15^{*}$ & $0.15^{*}$ & $-0.15^{*}$ & $0.31^{* *}$ & $0.32 * *$ & & $0.18^{*}$ \\
\hline Protection & & & & & $-0.17^{*}$ & $0.37^{* * *}$ & * $0.31 * *$ & & $0.20 * *$ \\
\hline Provision & & & & & & $0.30 * *$ & $0.29 * *$ & & $0.17 *$ \\
\hline \multicolumn{10}{|c|}{ School - Importance } \\
\hline \multicolumn{10}{|l|}{ Self- } \\
\hline determination & $0.17^{*}$ & $0.16 *$ & $0.15^{*}$ & $0.15^{*}$ & $-0.28 * *$ & $0.16^{*}$ & $0.35^{* * *}$ & $* 0.15 *$ & $0.24 * *$ \\
\hline Instruction & $0.22 * *$ & & $0.16^{*}$ & $0.17 *$ & $-0.24 * *$ & $0.30 * *$ & $0.35^{* * *}$ & * $0.18 *$ & $0.29 * *$ \\
\hline Esteem & $0.18^{*}$ & & $0.15^{*}$ & $0.16 *$ & $-0.15^{*}$ & $0.25^{* *}$ & $0.35^{* * *}$ & & $0.28 * *$ \\
\hline Relation & $0.24^{* *}$ & & $0.18^{*}$ & $0.15^{*}$ & $-0.19 *$ & $0.20 * *$ & $0.29 * *$ & & $0.25 * *$ \\
\hline Protection & $0.24^{* *}$ & & $0.20 * *$ & $0.18^{*}$ & $-0.12 * *$ & $0.32 * *$ & $0.34 * * *$ & & $0.28 * *$ \\
\hline Provision & & & & & & $0.15^{*}$ & $0.27^{* *}$ & & $0.24 * *$ \\
\hline \multicolumn{10}{|l|}{ Home- Existence } \\
\hline \multicolumn{10}{|l|}{ Self- } \\
\hline determination & $0.18^{*}$ & $0.15^{*}$ & $0.17 *$ & $0.18^{*}$ & $-0.18^{*}$ & $0.25^{* *}$ & $0.49 * * *$ & *0.19* & $0.38 * * *$ \\
\hline Instruction & $0.17^{*}$ & $0.16 *$ & $0.17^{*}$ & $0.17 *$ & $-0.20 * *$ & $0.15^{*}$ & $0.45^{* * *}$ & $* 0.21 * *$ & $0.25^{* *}$ \\
\hline Esteem & $0.16^{*}$ & $0.15^{*}$ & $0.18 *$ & $0.19 *$ & $-0.18^{*}$ & $0.31^{* *}$ & $0.42^{* * *}$ & *0.18* & $0.24 * *$ \\
\hline Relation & $0.17 *$ & $0.15^{*}$ & $0.16 *$ & $0.18^{*}$ & $-0.18^{*}$ & $0.22^{* *}$ & $0.46 * * *$ & $* 0.17 *$ & $0.28 * *$ \\
\hline Protection & $0.23^{* *}$ & o.19* & $0.23 * *$ & $0.22 * *$ & $-0.19 *$ & $0.15^{*}$ & $0.48^{* * *}$ & $* 0.17 *$ & $0.34^{* *}$ \\
\hline Provision & & & & & & $0.15^{*}$ & $0.39 * * *$ & & $0.27 * *$ \\
\hline \multicolumn{10}{|c|}{ Home-I Importance } \\
\hline \multicolumn{10}{|l|}{ Self- } \\
\hline determination & $0.15^{*}$ & $0.15^{*}$ & $0.15^{*}$ & $0.15^{*}$ & $-0.21^{* *}$ & $0.17^{*}$ & $0.28 * *$ & $0.16^{*}$ & $0.27 * *$ \\
\hline Instruction & & & & & $-0.15^{* * *}$ & $0.19 *$ & $0.29 * *$ & $0.17^{*}$ & $0.23 * *$ \\
\hline Esteem & & & & & $-0.17^{*}$ & $0.24^{* *}$ & $0.26 * *$ & & $0.19 *$ \\
\hline Relation & $0.15^{*}$ & & $0.17 *$ & $0.15^{*}$ & $-0.15^{*}$ & $0.16^{*}$ & $0.19^{*}$ & & $0.20 * *$ \\
\hline Protection & $0.17^{*}$ & & $0.19 *$ & $0.22^{* *}$ & $-0.29 * *$ & $0.31^{* *}$ & $0.30 * *$ & & $0.24 * *$ \\
\hline Provision & & & & & & $0.15^{*}$ & $0.24 * *$ & & $0.16^{*}$ \\
\hline
\end{tabular}

* $\mathrm{p}<0.05$; ** $\mathrm{p}<0.01$; *** $\mathrm{p}<0.001$

NC, Natural Sciences; MAT, Mathematics; HIS, History; ML, Mother Language; VIOL, Violence; PTS, Perception of Teacher's Support; PPS, Perception of Parental Support; BR, Brotherhood; TC, Trust in one's capacities

Table 5 presents the Pearson's correlation coefficients between the dimensions of the rights and the independent variables relating to school, home and personal conditions.

For school-existence concerns, significant correlations can be 
observed between the dimensions of the rights and the following variables: perception of teacher's support (PTS), perception of parent's support (PPS), trust in one's capacities (TC) and violence (VIOL). The coefficients of correlation existing between the dimension relation and the variables of school achievement - Natural Sciences (NC), History (HIST) and Mother Language (ML) - also deserve attention. The presented correlations are all positive except the ones for relationships with the variable violence.

For school-importancesignificant correlation coefficients were found in most of the occurrences. However, it must bestressed that the results in Mathematics (MAT) can only be significantly correlated with selfdetermination; and brotherhood (BR) can only be correlated with instruction and self-determination.

For home-existence nearly all the dimensions of the rights present statistically significant correlations with all the variables (school, home and personal)Theexception is provision which is only correlated with the following variables: perception of teacher's support ( $p<0.05)$, perception of parent's support ( $p<0.001$ ) and trust in one's capacities $(p<0.01)$. The greater correlations appear with the variable perception of parent's support ( $p<0.001)$, and thelesser with theachievement in Mathematics $(p<0.05)$.

For home-importance, there are significant correlations between the dimensions of the rights and the following variables: perception of teacher's support, perception of parental support, trust in one's capacities and for violence which is negatively correlated. Among other independent variables only the dimensions of self-determination, relation and protection present significant values. Theresults in Mathematics (MAT) can only be correlated with self-determination.

In short, provision appears to be the dimension of the rights which presents a lesser correlation, and the dimensions which are most correlated with the considered independent variables are protection and social-emotional relationship. The independent variables which do present greater correlations, with superior levels of statistical significance, are: perception of parental support, trust in one's capacities, and perception of teacher's support.

\section{Discussion and conclusions}

Onegeneral point which should bestressed is that Portuguese students recognize that their rights do exist not only in the school setting but also in their families, and that they are very important. The analyses conducted establishes that generally theexistence of rights is considered greater at homethan at school. This fact can ber el ated totheimportance given torights at home, which is far greater than for school. Thefindings 


\section{Veiga: Students' Perceptions of their Rights in Portugal}

also indicate that students have much higher expectations for their rights in a school setting, beyond what they judgeto besupported by that setting. In fact, it is a general finding that the importance of rights appeared to be greater than its existence, at school as well as at home, in most countries participating in the research project (Hart, 1996). Thus, and in spite of the general average of good results obtained, home and, particularly school, appear to be the places where the rights of the children should be specially promoted.

Consideration of findings for the school context allows us to state that thestudents who givel ower judgements of the importanceand existence of rights at school, as well as in their homes can be characterized in the following ways: of inferior academic performance in school (with a greater school failure or with a lower school achievement), violent students and children who have perception of a lower degree of teacher support and students who lack confidence in their own capacities. The collected data allow the identification of teacher's support as one of the best ways to strengthen the existence of students' rights. The ability of theteacher to show to thestudent how hecares for this person (E rikson, 1980), as well astheconsideration for his/her self-determination (Maslow, 1970), are seen as special ways of giving value to the person. This information is consistent with other studies (Dreikurs et al., 1982; Veiga, 1995), suggesting the need of a model of teacher training including the following aspects: competencies of evaluation, training on human relationships among students of different educational levels, promotion of assertiveness in students, development of the child's confidence in his/ her capacities, in short the teacher's supportive availability for education.

Rights did also seem to exist less among students of adverse family contexts- low parents' education, authoritarianism, divorce/separation, low degree of parental support, low degree of brotherhood, exposure to aggressive TV shows - a fact which goes along with other studies (Oliveira, 1994; Veiga, 1997). Among all the variables, the one considered as the most important of all is parental support. Parental support seems to be the most important parameter to take into consideration in the promotion of the rights perceived by the students in their families. Parents' training, especially in competencies such as understanding, supporting and capacity of accompanying their children, should be an important component of future projects in order to promote the rights of children.

The personal variables did also appear related to the rights. When gender is considered, the equality of rights between boys and girls suggests that social contexts have had the tendency to eliminate the traditional discriminatory differences (Hurtig and Pichevin, 1986). Age does seem to favour younger students (12- to 13-year-old): the greater 
School Psychology International (2001), Vol. 22(2)

perception of existence of rights among students of these ages than among the older ones may be related to the greater need of affirmation among older students, striving towards construction of her/his new identity and independence (Erikson, 1980; Veiga, 1995). One may also raise the hypothesis of a positive evolution in the direction of an increasing social valuing of children's rights. This hypothesis could be tested later on in longitudinal studies. Where aimed profession is concerned, the rights of students who aim at a lower profession are also lower. It is likely that the expectation of a shorter period in school may be associated with poorer home and school conditions, leading to lower expectations for thesatisfaction of such rights (F ontaine, 1991; Loranger et al., 1987).

This study allows us to highlight certain implications for the educational psychologist and his/her practice. Using the Children's Rights Scale (CRS) may yield important information on those students who need counselling. On the other hand, educational psychologists' use of theCRS will hel ptheelaboration of plans for promoting children's rights at school and at home. The implementation of these programs should first consider students with a low level of assertiveness and weak results in school.

In short, Portuguese students declare that their rights exist and are very important. It should be noted that it is precisely those children who have more personal limitations or who have worse school settings or home contexts who giveless importance and lower existence of rights at school and at home. Finally, the present study all ows us to highlight the idea that projects for the promotion of children's rights should include training programs for teachers and parents, in a net connection including school, home and relevant social agents. Brofenbrenner's (1986) ecological model of human development may be used as a theoretical frame for such projects. Educational psychologists may develop an important role in these projects.

\section{References}

Bronfenbrenner, U. (1986) 'E col ogical Systems Theory', in R. Vasta (ed.), Annals of Child Development, vol. 6, pp. 187-251. Greenwich, CT: J Al .

Deci, E. and Ryan, R. M. (1985) Intrinsic Motivation and Self-Determination in Human Behavior. New York: Plumen.

Dreikurs, R., Grunwald, B. and Pepper, F. (1982) Maintaining Sanity in the Classroom (2nd edn). New York: Harper and Row.

Erikson, E. H. (1980) I dentity and the Life Cycle (2nd edn). New York: Norton.

Fontaine, A. M. (1991) ‘O conceito de si próprio no ensino secundário: processo de desenvolvimento diferencial', Cadernos de Consulta Psi cológi ca 7: 33-54.

Hart, S. (1993) 'Children's Rights Perspectives of Youth and Educators: Early Findings of Cross National Project', The I nternational J ournal of Childrens' Rights 1: 165-88. 


\section{Veiga: Students' Perceptions of their Rights in Portugal}

Hart, S. N., Zneider, M . and Pavlović, Z. (1996) ‘Childen's Rights: Cross National Research on Perspectives of children and their Teachers', in M. J ohn (ed), Children in Charge: The Child' Right to a Fair Hearing, pp. 38-58. London: J essica Kingsley Publishers.

Hurtig, M. C. and Pichevin, M. F . (1986) La différence des sexes: Questions de psychologie Paris: Editions Tierce.

Loranger, M. (1987) Les conduites sociales des adolescents à l'école. Québec: Université Laval.

Maslow, A. H. (1970) Motivation and Personaliy (2nd”a edn). New York: Harper and Row.

Oliveira, J . H. B. (1994) Psicologia da Educação Familiar. Coimbra: Livraria Almedina.

Veiga, F. H. (1995) Transgressão e Autoconceito dos J ovens na Escola (2nd Edição)Lisboa: Editora Fim de Século.

Veiga, F . H. (1996) 'E studo de um Instrumento de Autoconceito E scolar: O SelfConcept as a Learner Scale', in L. Almeida et al. (ed.) Avaliação Psi cológica: Formas e Contextos. Braga, pp 365-80. Coimbra: APPORT.

Veiga, F . H. (1997) Autoconceito dos jovens: Análise em função de variáveis do contexto familiar. Actas do I Congresso Luso-Espanhol de Psicologia da Educação. Coimbra: APPORT.

Veiga, F . H . (1999) In discipl ina eviolência na escola: Práticas com unicacionais pasra professores e pais. Coimbra: Almedina. 